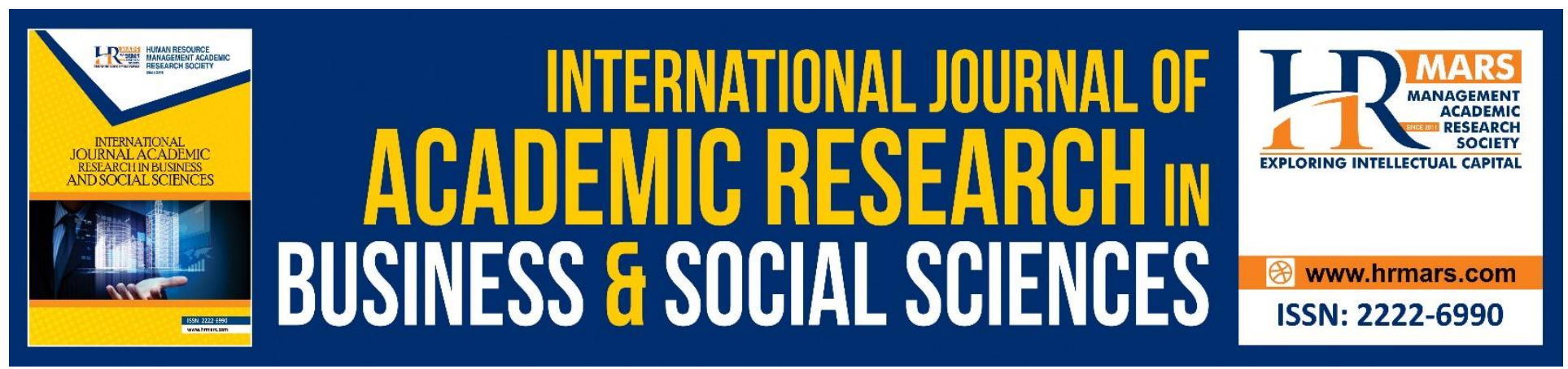

\title{
Music as a Factor in Spiritual Happiness: A Case Study on Senior Citizen in Darul Hanan Elderly Care Centre, Penang
}

Nurul Hidayawatie Mustaffa, Noor Shakirah Mat Akhir

To Link this Article: http://dx.doi.org/10.6007/IJARBSS/v10-i10/8005

DOI:10.6007/IJARBSS/v10-i10/8005

Received: 08 August 2020, Revised: 26 August 2020, Accepted: 19 September 2020

Published Online: 27 October 2020

In-Text Citation: (Mustaffa, \& Akhir, 2020)

To Cite this Article: Mustaffa, N. H., \& Akhir, N. S. M. (2020). Music as a Factor in Spiritual Happiness: A Case Study on Senior Citizen in Darul Hanan Elderly Care Centre, Penang. International Journal of Academic Research in Business and Social Sciences. 10(10), 718-730.

Copyright: (c) 2020 The Author(s)

Published by Human Resource Management Academic Research Society (www.hrmars.com)

This article is published under the Creative Commons Attribution (CC BY 4.0) license. Anyone may reproduce, distribute, translate and create derivative works of this article (for both commercial and non-commercial purposes), subject to full attribution to the original publication and authors. The full terms of this license may be seen

at: http://creativecommons.org/licences/by/4.0/legalcode

Vol. 10, No. 10, 2020, Pg. 718 - 730

http://hrmars.com/index.php/pages/detail/IJARBSS

JOURNAL HOMEPAGE

Full Terms \& Conditions of access and use can be found at http://hrmars.com/index.php/pages/detail/publication-ethics 


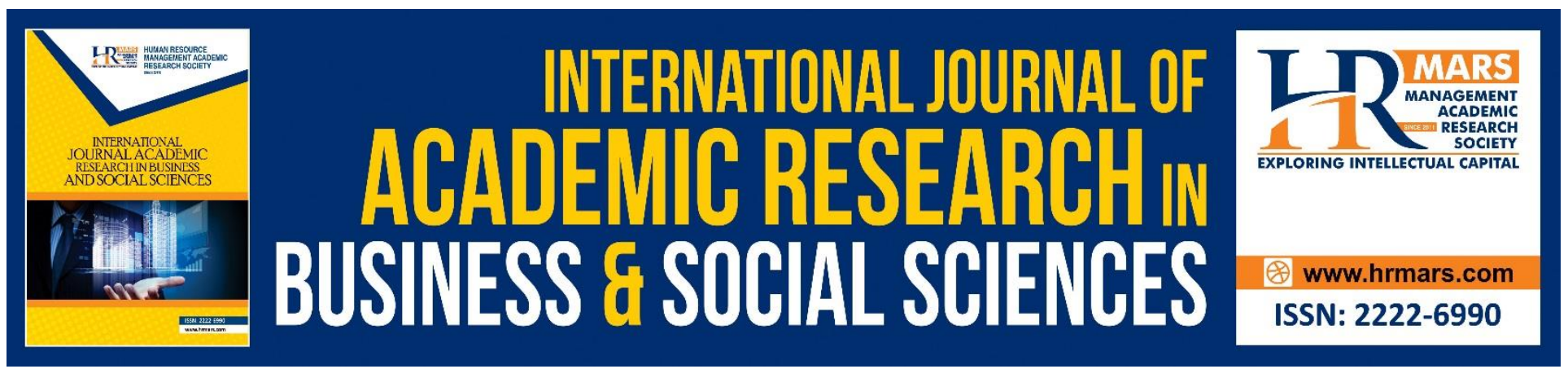

\title{
Music as a Factor in Spiritual Happiness: A Case Study on Senior Citizen in Darul Hanan Elderly Care Centre, Penang
}

\author{
Nurul Hidayawatie Mustaffa, Noor Shakirah Mat Akhir \\ Pusat Pengajian IImu Kemanusiaan, Universiti Sains Malaysia, 11800 Pulau Pinang, Malaysia. \\ Email: shakirah@usm.my
}

\begin{abstract}
Music is a universal element unanimously deemed as entertainment in human life and received differently in communities. Music is identical to young people but not exclusive to them per se. The senior citizens too are not immune from listening to music for their pleasure past times. The effectiveness of music for the elderly as a factor of spiritual happiness is however uncertain and it leaves room for research. Therefore, this study aims to examine the role of music as a factor of spiritual happiness for the senior citizen. In this research, its qualitative study attempts to identify the happiness factor for the elderly stemming from music, using data collected from field study that which involves questionnaires and semi-structured interviews with ten senior citizens selected for the purpose who reside in an elderly care centre named Pusat Jagaan Warga Emas Darul Hanan Pulau Pinang in the state of Penang. The study finds that all ten senior citizen surveyed, agree that music is a factor that can raise spiritual happiness in them. This alone is evident that music is indeed able to yield spiritual happiness to the elderly in this care center and fit for use as entertainment so long as it is not contrary to the context allowed in Islam. Music genre such as marhaban, qasidah, nashid are often the music of choice for this group of age.
\end{abstract}

Keywords: Music, Factors, Happiness, Spirituality, Senior Citizen.

\section{Introduction}

Music is an arrangement of sounds that produces beautiful and pleasant shapes and rhythm like melody, songs, tune and hum (Dewan, 2017). Music is a universal element deemed as entertainment in human's life and accepted in communities in its variant forms and genres traversing societies such as lullabies, healing songs, dance songs and love songs (Gottlieb, 2019; Mehr et al. 2019; Asprou, 2020; Brown and Jordania, 2011; Johnson, 2002; Letts, 1997; Ahmad, 2004).

Happiness means contentedness, pleasure in life, fortunateness and luckiness (Dewan, 2017). Happiness is sa'adah in Arabic. The root word for sa'adah, spelled with characters sin 'ayn dal ( 1 ( w) appears twice in the Qur'an, among which with the pronunciation su 'idu which means "in happiness" (Hūd: 108; The Quranic Arabic Corpus, 2017). Sa'adah also means well-being, comfort and 
INTERNATIONAL JOURNAL OF ACADEMIC RESEARCH IN BUSINESS AND SOCIAL SCIENCES Vol. 10, No. 10, 2020, E-ISSN: 2222-6990 @ 2020 HRMARS

ultimate happiness (Al-Mawrid, 1995; Akhir, 2008). Spiritual means interior/inward and is relevant to soul (Kamus Dewan, 2017). Spiritual in Arabic is known as rūhani. The root word for rūhani, i.e. ra waw ha (נر ( ) appears 57 times in the Qur'an, among which is the pronunciation of birūhin which means "with spirit" (al-Mujadilah: 22; The Quranic Arabic Corpus 2017). Rūhani also means soul, intangible, invisible and abstract (Al-Mawrid, 1995; Sa'ari, 1997).

Music plays an important role in lives of human. Among others music can be a factor for reducing stress and anxiety based on the effect of music on the human body. Among the musical elements involved are rhythm/beat (tempo), harmony and melody. The element of harmony is the key to stimulating the feelings of positivity. Music has also a role in decreasing the symptoms of psychological stress such as adrenalin, heart rate, as well as blood pressure through listening to music, singing or playing music (Clark and Tamplin, 2016). Moreover, music also helps in the learning process and it is found that students who listen to the genre of classical music often obtain better results compared to students who listen to the genre of hip-hop and rap music (Kent, 2006).

Based on the discussions, it is observed that music does give a positive effect in human's life. However, it is unclear as to the role of music in spiritual happiness to human beings, including the elderly. Therefore, this research was conducted to study music as a factor of spiritual happiness upon senior citizen in Darul Hanan, Penang.

\section{Music in Islam}

In general, playing music and the term music itself are non-existent in the Qur'an (Yusof and Bidin, 2008; Ab. Majid and Yusof, 2008). However, the scholars of the past, al-Ghazali (d. 505H / 1111 AD) discusses the acceptable music and dance in Islam, in his work entitled Kimiya 'al-Sa'adah (the Alchemy of Happiness). Similarly, contemporary scholar, al-Qaradhawi (1997) also discusses music in his work entitled Al-Halal Wal-Haram Fil Islam (The Lawful and the Prohibited in Islam).

According to al-Ghazali (2004), beside obedience and worship to Allah Subhanahu wa Ta'ala (SWT), music and dances may be made mediums in religious worship. This privilege is accorded to the people who have immense reverence and love towards Allah (SWT). Through music, they manifest their longing and yearning for Allah SWT through self-composed poems as found in genres the likes of marhaban, qasidah and nashid. Listening to music as a form self-entertainment is also not forbidden; for example, listening to the sound of birds chirping or listening to the sound of trickling water. In addition, music which arouses the spirit within oneself such as songs commonly sung to cheer Muslims performing Hajj as well as those that evoke fighting spirit to battle against the infidels are also allowed. Similarly, melancholy songs that mellow the soul to induce one's remorse for the sins committed or the failure in performing religious duties. Music is likewise accepted in weddings, thanksgiving and homecoming of those who travelled (al-Ghazali, 2004), such as the song of Tala 'alBadru' Alayna. Along with marhaban, qasidah and nashid, the practice of barzanji is also included in the context of permissible music. In fact, this practice is well received in the local community as they are often performed in wedding ceremony and celebrating the birth of Prophet Muhammad Solla'Llahu 'alayhi wa sallam (SAW) (Samat et al., 2014).

Among the characteristics of music that are allowed as a past-times activity are encrusted in the following hadith which reads:

From A'ishah radiy Allah" anha (RA) she says: "Abū Bakr radiy Allah" anhu (RA) came to my house while the two Ansar girls were singing beside me about the story of the Ansar people and the day of Bu'ats. And both of them are not singers. Abū Bakr protested saying: "musical instrument of 
INTERNATIONAL JOURNAL OF ACADEMIC RESEARCH IN BUSINESS AND SOCIAL SCIENCES Vol. 10, No. 10, 2020, E-ISSN: 2222-6990 @ 2020 HRMARS

Satan in the house of Rasulullah SAW!" This happened during the 'eid celebration Rasulullah SAW said: "O' $A b \bar{u}$ Bakr, each race has their respective celebration and today is our celebration." (Sahih alBukhari, Book 13, Hadith 4; Sahih al-Bukhari, v. 1, p. 278; Al-Ghazali, 2004).

From 'A'ishah RA she says: "Rasulullah SAW came to my house when two Ansar girls near me were singing the story of Ansar people regarding the day of Bu'ats. Rasulullah SAW lied down and turned his face in the other direction. Then, Abū Bakr RA came and spoke to me harshly, "musical instrument of Satan near Rasulullah SAW?" Rasulullah SAW turned towards Abū Bakr and said: "leave them". At that time Abū Bakr did not heed so I gestured to the girls to leave and they left. The day was Eid celebration and Sudanese were playing swords and shields. Either I requested or Rasulullah SAW asked me, saying: "do you want to go see the display?" I replied: 'Yes". Then Rasulullah made me stand behind him and my cheek was touching his cheek and he was saying: "Carry on! O' Bani Arfida" until I got tired. Rasulullah SAW asked me, "Are you satisfied?" I replied "Yes" and he asked me to leave." (Sahih al-Bukhari, Book 13, Hadith 2; Sahih al-Bukhari, v. 1, p. 277; Al-Ghazali, 2004).

Based on the hadith, it is clear that music is allowed in certain context such as during Eid celebration. According to al-Qaradhawi (1997), singing is one of entertainment forms which can calm the soul, delight the heart and refresh hearing as long as the song does not impair the morals of Muslims. He also quotes the above hadith in concert with al-Ghazali that singing is permitted in celebrations such as Eid, wedding feasts, birth ceremonies and 'aqiqah feasts as well as welcoming the return of travellers. Al-Qaradhawi views that music is not haram and everything depends on intention as Rasulullah SAW says:

"Every action must be accompanied by intention. The reward for every human deeds, is the reward for what he intends." (Sahih al-Bukhari, Book 1, Hadith 1; Sahih al-Bukhari, v. 1, p. 1)

According to al-Qaradhawi (1997), one who listens to music for the purpose of uplifting his spirit to acquire strength to worship Allah, do good deeds in order to become a good and obedient servant of Allah, thus, his action of listening to music is justified. The same can be said of other entertaining activities which are not harmful such as taking a walk in parks, standing by the window appreciating the sky, wearing a blue attire and so much more are all allowed. Al-Qaradhawi however cautions on the limitations pertaining to the permissibility of singing and music in which, the singing should be performed in a modest and non-sensual manner, not excessive to the extent of neglecting other responsibilities and music must be avoided in the event of the presence of harms and danger and should be prohibited in total if the musical engagements were associated with forbidden activities or matters such as drinking alcohol (al-Qaradhawi, 1997; Che Seman, Awang Kechik \& Ahmad, 2014; Frishkopf, 2008).

The above discussions clearly indicate that music is allowed in the context concurred by Islam examples of which can be illustrated by music which reminds the listener to Allah SWT when listening to it and gives rise to other actions of piety such as improving the practice of worship, inspiring the desire to perform Hajj, instigating fighting spirit against the infidels and increasing love for Allah. Music is even allowed if it is simply for the sake of entertainment as is during weddings as long as it is not tainted with non-sharia compliant activities. Music which develops deep sense of love for Allah is highly encouraged so as to purify the hearts from matters of immorality and neglect from remembrance of Allah (Parman, Shahri \& Marni, 2017). 
INTERNATIONAL JOURNAL OF ACADEMIC RESEARCH IN BUSINESS AND SOCIAL SCIENCES Vol. 10, No. 10, 2020, E-ISSN: 2222-6990 @ 2020 HRMARS

\section{Music and the Elderly}

Music typically is the domain of young people (Ulfa, 2017; Papinczack et al. 2015; Beckmann, 2013; Dearn, 2013). The elderly is no exception though when it comes to listening to music for the pleasure of their hearing. In a study on senior citizen who resided in religious-based elderly care centre, it was found that the activities carried out in the centre were the determining factors on whether or not the elderly would want to take residence at such centre. Among the activities carried out were qasidah session and talks. Participation in these activities filled up their free time positively when they chose religious-style elderly home care (Abu Bakar et al., 2016).

Music also serves as a medium of $d a^{\prime}$ wah to the elderly. Among the genres of music utilized as $d a^{\prime} w a h$ to them is zikr therapy. It is a technique to sooth the souls of the elderly because it is replete with the melodious recitations and excerpts from the holy scriptures which glorify Allah SWT and is able to induce repentance and mellow the hearts of anyone who listens. This zikr therapy method is done by way of loud speaker each morning from 8.00am - 9.30am for the residents of Rumah Ehsan elderly home care. Among the zikr played over the loud speaker are zikr munajat of 'Astaghfirullah', 'Subhanallah', healing verses and also Ma'thurat in the morning and evening. Studies have shown that this technique is very effective because it touches the souls of the elderly and makes them remorseful (Abd. Rahman et al., 2018).

If on the local front, music genres such as zikr therapy is used as a means of $d a^{\prime} w a h$ for the elderly, the situation is quite on the contrary abroad; where music therapy is used to reduce the symptoms of illness in senior citizen. To illustrate, music therapy is able to influence the behaviour of the elderlies who suffer from dementia in a positive way; i.e by reducing anxiety in dementia patients. In addition, positive effects can also be seen on the mood swings and social ability of seniors undergoing music therapy (Wall and Duffy, 2010). Moreover, music also plays a role in reducing depression and pressure off the elderlies as well as improves their quality sleep through soothing music, apart from helping to reduce pain and insomnia of the elderlies in palliative care (Hanser and Thompson, 1994; Lai and Good, 2005; Botek, 2020).

It is obvious from the discussion that the role of music for senior citizen exists in a variety of forms. Evidently music brings out positive effects on senior citizen. However, the role of music as a factor in thorough spiritual happiness for the elderlies is still vague and leaves a big room for research. Thus this paper attempts to study music as a factor of spiritual happiness for the senior citizen at the Elderly Care Center, Darul Hanan, Penang, in four aspects.

\section{Research Methodology}

This is a case study research involving qualitative methods by way of data collection gained from field research. Field research is data collection method pertaining to man and his natural surroundings, warranting the researcher to embark into field study to conduct physical research (Ahmad, 2017). This field study involves questionnaire method and semi-structured interview with ten senior citizens selected by sampling at Pusat Jagaan Warga Emas Darul Hanan, Penang. The small number of respondents is relevant based on the interview method conducted to obtain in-depth information and answer the questions in this study (Puvenesvary et al., 2008). The research tools used were interview protocols and questionnaires. The technical tools used was an audio recorder. The four aspects studied on the ten senior citizens pertaining to music as a factor for spiritual happiness were the level of knowledge of senior citizen about permissible music in religion, the feelings experienced after listening to music, the practice of listening to music in daily life and the 
INTERNATIONAL JOURNAL OF ACADEMIC RESEARCH IN BUSINESS AND SOCIAL SCIENCES Vol. 10, No. 10, 2020, E-ISSN: 2222-6990 @ 2020 HRMARS

preferred genre of music by the elderlies. Interview data were analysed qualitatively through the process of transcription, reduction, coding and data display. Meanwhile, data from the questionnaire was analysed descriptively and the data display is presented in the form of diagrams and tables (Puvenesvary et al., 2008). Questionnaires data were analysed qualitatively due to the relatively small size of sample of only ten respondents and SPSS method which usually uses relatively large sample size was not employed (Howell, 2008).

\section{Analysis of Study Findings and Factors of Elderly Spiritual Happiness}

\section{A) Background Analysis of Respondents}

The background analysis of the respondents was made from the data acquired via questionnaire method. Through intentional sampling, a group of ten residents of Pusat Jagaan Warga Emas Darul Hanan, Penang were selected as respondents. To maintain the confidentiality of the respondents, they are identified with pseudonyms. For example, respondent $A$ is referred to as $R A$, respondent $B$ as $R B$ and so on namely RC, RD, RE, RF, RG, RH, RI and RJ. The list and the background of respondents are tabled as follows:

Table 1: List and Background of Respondent

\begin{tabular}{|c|c|c|}
\hline Respondent & Age & Questionnaire and Interview date \\
\hline 1. RA & 77 years & 22 September 2019 \\
\hline 2. RB & 77 years & 20 October 2019 \\
\hline 3. RC & 83 years & 20 October 2019 \\
\hline 4. RD & 64 years & 26 October 2019 \\
\hline 5. RE & 77 years & 25 November 2019 \\
\hline 6. RF & 59 years & 28 November 2019 \\
\hline 7. RG & 71 years & 3 December 2019 \\
\hline 8. RH & 80 years & 3 December 2019 \\
\hline 9. RI & 74 years & 12 December 2019 \\
\hline 10. RJ & 69 years & 19 December 2019 \\
\hline
\end{tabular}

Source: Questionnaire Form

The above Table 1 exhibits a number of six respondents whom are RA, RB, RE, RG, RH and RI in the age range of 71 to 80 and are the most respondents involved in this study. Followed by two respondents, RD and RJ aged between 61 and 70 years old while the fewest respondents are those aged between 51 and 60 years old, known as RF and RC aged between 81 years and above.

\section{B) Analysis of Music as a factor of Spiritual Happiness of Senior Citizen}

This analysis involves four research aspects namely the level of knowledge of respondents on the permissible music in religion, the feelings they experienced after listening to music, the practise of listening to music in their daily lives and the genre of music of their choice.

\section{i) The Level of Respondent's knowledge on Acceptable Music to Religion}

Based on the data from the questionnaire, all respondents admit that they have knowledge of which type of music is allowed by religion i.e. marhaban, qasidah and nashid. The findings for this questionnaire in the form of checklists are tabled as follows: 
INTERNATIONAL JOURNAL OF ACADEMIC RESEARCH IN BUSINESS AND SOCIAL SCIENCES

Vol. 10, No. 10, 2020, E-ISSN: 2222-6990 @ 2020 HRMARS

Table 2: The Level of Knowledge of Music Permissible in Religion

\begin{tabular}{cc}
\hline Respondent & Knowledge of music allowed in religion \\
\hline $1 . \mathrm{RA}$ & $\mathrm{V}$ \\
\hline $2 . \mathrm{RB}$ & $\mathrm{V}$ \\
\hline $3 . \mathrm{RC}$ & $\mathrm{V}$ \\
\hline $4 . \mathrm{RD}$ & $\mathrm{V}$ \\
\hline $5 . \mathrm{RE}$ & $\mathrm{V}$ \\
\hline $6 . \mathrm{RF}$ & $\mathrm{V}$ \\
\hline $7 . \mathrm{RG}$ & $\mathrm{V}$ \\
\hline $8 . \mathrm{RH}$ & $\mathrm{V}$ \\
\hline $9 . \mathrm{RI}$ & $\mathrm{V}$ \\
\hline $10 . \mathrm{RJ}$ & $\mathrm{V}$ \\
\hline
\end{tabular}

Source: Questionnaire Form

Table 2 shows the vast knowledge of the respondents in the types music which are permitted in religion is satisfactory.

\section{ii) Respondents' Feelings after Listening to Allowed Music in Religion}

Based on the questionnaire, all respondents admit that they are happy when listening to music allowed by religion. The findings deduced from the questionnaire in list form is summarised as follows.

Table 3: The Feelings of the Respondents after Listening to Music Allowed in Religion

\begin{tabular}{cc} 
Respondent & $\begin{array}{c}\text { Feeling happy after listening to } \\
\text { music }\end{array}$ \\
\hline 1. RA & $\mathrm{V}$ \\
\hline 2. RB & $\mathrm{V}$ \\
\hline $3 . \mathrm{RC}$ & $\mathrm{V}$ \\
\hline $4 . \mathrm{RD}$ & $\mathrm{V}$ \\
\hline 5. RE & $\mathrm{V}$ \\
\hline $6 . \mathrm{RF}$ & $\mathrm{V}$ \\
\hline 7. RG & $\mathrm{V}$ \\
\hline 8. RH & $\mathrm{V}$ \\
\hline 9. RI & $\mathrm{V}$ \\
\hline $10 . \mathrm{RJ}$ & $\mathrm{V}$ \\
\hline & Source: Questionnaire Form
\end{tabular}

Based on the Table 3, it is apparent that music is a factor in raising spiritual happiness to the respondents.

\section{iii) The Practise of Listening to Music in Everyday Life}

The data collected for the interview exhibits all the respondents admit that they made the practise of listening to religion approved music as their daily routine. The following table concludes the 
INTERNATIONAL JOURNAL OF ACADEMIC RESEARCH IN BUSINESS AND SOCIAL SCIENCES Vol. 10, No. 10, 2020, E-ISSN: 2222-6990 @ 2020 HRMARS

answers of the respondents when asked whether they listen to music acceptable to religion in their daily lives.

Table 4: The Practice of Listening to Music in Daily Lives

\begin{tabular}{ll}
\hline Respondent & Respondent's answer to question on listening to music allowed in religion \\
\hline 1. RA & "yea, nashid, yea, yes..." \\
\hline 2. RB & "Well, we also want fun, yea, entertainment ..." \\
\hline 3. RC & "no music. Laila ha ilallah only." \\
\hline 4. RD & "Yes, sometimes nashid, a, if songs like Selimut Putih.." \\
\hline 5. RE & "Yes, I do.." \\
\hline 6. RF & "Nashid..yes, I do.." \\
\hline 7. RG & "yea, marhaban, yea, partly.." \\
\hline 8. RH & "Yes, yes.." \\
\hline 9. RI & "yea, those which appeal to us we listen to the songs, there are religious \\
& advices in there, yea..." \\
\hline 10. RJ & "yea, nashid, that's it, that suffices, it does become practice, it is enough .." \\
\hline
\end{tabular}

The Table 4 illustrates that all respondents listen to music allowed by religion as a daily routine in their lives.

\section{iv) The Musical Genre that Appeals to the Respondents}

The interview conducted with the respondent reveals their musical genre of choice as follows:

i. Nashid: A number of five respondents choose this genre of music. This is particularly so, given the fact that nashid contains religious advices and immensely interested in by a respondent (RI, $12^{\text {th }}$ December, 2019). The song enjoyed by the respondent is the likes of Selimut Putih (white shroud) sung by a nashid group by the name EI Suraya (RD, 26 ${ }^{\text {th }}$ October, 2019). Nashid too has been a routine in the daily activity of respondent (RJ, 19 ${ }^{\text {th }}$ December, 2019). RA and RF too mention nashid as their preferred genre of music when asked on the practice of listening to music in their daily lives (RA, $22^{\text {nd }}$ September 2019; RF, 28 ${ }^{\text {th }}$ November 2019).

ii. Marhaban and qasidah: One respondent, RG chooses marhaban as his favourite music genre and makes listening to music as part of his daily practice. (RG, $3^{\text {rd }}$ December, 2019). RE and RH agree with the genre of music suggested when interviewed. RE agrees with music genre the likes of nashid and marhaban (RE, $25^{\text {th }}$ November 2019) while RH agrees with qasidah being his preferred genre of music (RH, $3^{\text {rd }}$ December, 2019).

iii. Tahlil: One respondent, RC specifies tahlil as his favoured music genre, which he describes as zikr Laila ha ilallah. He also refuses to listen to general music; where she answers: "No music. Laila ha ilallah only." (RC, 20 ${ }^{\text {th }}$ October, 2019).

iv. Others: One respondent, RB admits to listening to music permissible in religion but does not mention any genre of choice. Instead she concludes that music is fun and entertaining. When 
INTERNATIONAL JOURNAL OF ACADEMIC RESEARCH IN BUSINESS AND SOCIAL SCIENCES Vol. 10, No. 10, 2020, E-ISSN: 2222-6990 @ 2020 HRMARS

asked about music, RB answers: "Well, we also want fun, yea, entertainment..." (RB, 20 th October, 2019).

Based on the discussion, nashid becomes the music genre most favoured by with a total of five respondents, specifically RA, RD, RF, RI and RJ. This is followed by marhaban opted by RG, qasidah chosen by $\mathrm{RH}$ and tahlil by $\mathrm{RC}$ as respective genre of choice. While RE is interested in two genres of music, namely nashid and marhaban. One respondent, RB does not indicate any specific genre that interests her but admits that music is something fun and entertaining. The Figure 1 below summarizes these findings.

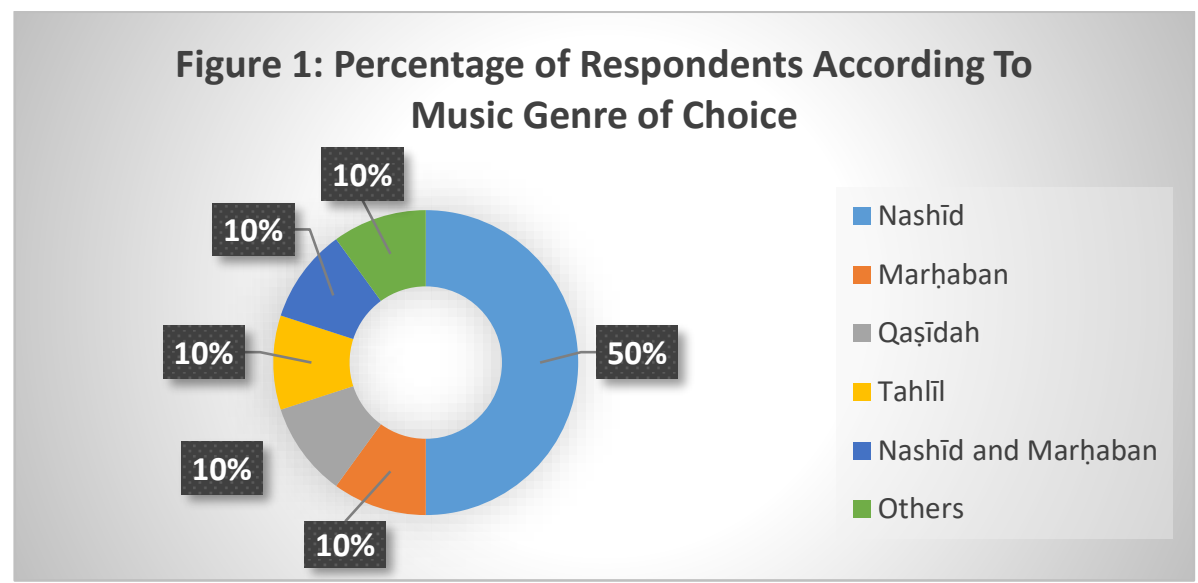

Source: Interview Transcript of the Respondents

Based on the Figure 1 above, a total of five respondents which constitutes $50 \%$ from the total sample studied prefer nashid as their main music genre of choice. Meanwhile, each of the rest of the respondents at $10 \%$ chooses marhaban, qasidah and tahlil as their respective preferred music genre making the whole of their collective percentage at 30\%. One respondent is interested in two genres of music that is marhaban and nashid constituting another $10 \%$ while another respondent at the percentage of $10 \%$ does not mention any genre of music of her choice, therefore she is placed under the category of others in the above figure.

\section{Discussions}

\section{Key Findings}

Based on the findings of the research, it is evident that music is a factor of spiritual happiness for senior citizen at this elderly care centre. The finding is derived from the four aspects of study conducted; that is firstly from the respondents' level of knowledge of the acceptable genre of music in religion which is satisfactory. Secondly, all respondents unanimously agree that they are happy when they listen to permitted music in religion. Thirdly, all respondents admit that listening to allowed music in religion are routine in their daily lives and finally, save for one, all respondents specify genre of music of respective choice, indicating that they truly have knowledge and fully understand the music genre such as nashid, marhaban and qasidah are the genres of choice of the respondents while tahlil and entertaining music are also the genre of choice for certain quarter of this age-group of people. 
INTERNATIONAL JOURNAL OF ACADEMIC RESEARCH IN BUSINESS AND SOCIAL SCIENCES

Vol. 10 , No. 10, 2020, E-ISSN: 2222-6990 @ 2020 HRMARS

\section{Recommendations for Further Study}

This paper suggests a further research as this research only discusses the role of music as a factor of spiritual happiness of selected senior citizen in Darul Hanan Elderly care centre, Penang. The future research can focus on the role of music in other elderly home care as well as exploring other functions of music, not only upon senior citizen but all walks of life.

\section{Conclusion}

The study finds that music is allowed so long as it is in the context permitted by Islam. The role of music is not only to entertain, but far reaching as a means to invoke remorse and repentance upon the listeners through lyrics that bring them to the remembrance of Allah SWT.

\section{Acknowledgements}

The authors want to thank the Fundamental Studies Grant, Malaysia Ministry of Education, 203 / PHUMANITI / 6711590.

\section{Corresponding Author}

Noor Shakirah Mat Akhir

School of Humanities

Universiti Sains Malaysia 11800,

Pulau Pinang, Malaysia.

Email:shakirah@usm.my

\section{References}

\section{Al-Qur'an}

Ab. Majid, M. K., \& Yusof, M. (2008). Ke arah memperkasakan Islamisasi seni muzik sebagai satu alternatif: Satu pengamatan awal. Jurnal Hadhari, Edisi Khas, $105-121$.

Abd. Rahman, R., Mohd. Haridi, N. H., Salleh, N., \& Zaini, A. R. (2018). Bentuk metodologi dakwah warga

emas: Analisis Rumah Ehsan Jabatan Kebajikan Masyarakat (JKM) (The form of da'wah methodologies of senior citizens: Rumah Ehsan Jabatan Kebajikan Masyarakat (JKM) analysis). Jurnal Pengajian Islam, 11 (1), 41 - 51.

Abu Bakar, S., Abd. Majid, M., Abdul Razak, A. Z., \& Ismail, S. (2016). Faktor pemilihan pondok oleh warga emas: Kajian di Pondok Yayasan al-Jenderami, Selangor dan Pondok Madrasah arRahmaniah ad-Diniah Lubuk Tapah, Kelantan. Jurnal Pengajian Islam, 9 (2), 1 - 23.

Ahmad, I. (2004). Muzik kontemporari sebagai alat pembentukan nilai dalam komuniti: Ke mana halatuju kita? Seminar Antarabangsa Nilai dalam Komuniti Pasca Modenisme (SIVIC 2004), 4 - 6 September 2004, Langkawi, 1 - 12. (Unpublished). http://repo.uum.edu.my/1853/. Retrieved on $17^{\text {th }}$ August 2020.

Ahmad, C. M. (2017). Fieldwork and the qualitative - interpretative analysis. Journal of Social Sciences and Humanities, Special Issue (1), $49-58$.

Akhir, N. S. M. (2008). Al-Ghazali and his theory of the soul a comparative study. Pulau Pinang, Malaysia: Penerbit Universiti Sains Malaysia.

Al-Bukhari, A. A. M. I. I., Sahih al-Bukhari Book 13, Hadith 4. https://sunnah.com/bukhari/13/4. Retrieved on $19^{\text {th }}$ August 2020. 
INTERNATIONAL JOURNAL OF ACADEMIC RESEARCH IN BUSINESS AND SOCIAL SCIENCES Vol. 10, No. 10, 2020, E-ISSN: 2222-6990 @ 2020 HRMARS

Al-Bukhari, A. A. M. I. I. Sahih al-Bukhari Book 13, Hadith 2. https://sunnah.com/bukhari/13. Retrieved on $19^{\text {th }}$ August 2020.

Al-Bukhari, A. A. M. I. I., Sahih al-Bukhari, Book 1, Hadith 1. https://sunnah.com/bukhari/1. Retrieved on $20^{\text {th }}$ August 2020.

Al-Bukhari, A. A. M. I. I. (2009). Sahih al-Bukhari Volumes I, II, III \& IV (H. Zainuddin Hamidy, H. Fachruddin Hs., H. Nasharuddin Thaha, J. Arifin \& A. Rahman Zainuddin M.A, Trans.). Kuala Lumpur, Malaysia: Klang Book Centre.

Al-Ghazali, A. H. M. I. M. (2004). The alchemy of happiness (C. Field, Trans.). http://data.nur.nu/Kutub/English/Ghazali_Alchemy-of-Happiness.pdf. Retrieved on $19^{\text {th }}$ August 2020.

Al-Qaradhawi, Y. (1997). The lawful and the prohibited in Islam (Al-Halal Wal-Haram Fil Islam). Cairo, Egypt: Al-Falah for Translation, Publishing and Distribution.

Asprou, H. (2020). Music is a universal language, new Harvard university study proves. Classic fM. https://www.classicfm.com/music-news/study-proves-music-is-universal-language/. Retrieved on $17^{\text {th }}$ August 2020.

Baalbaki, R. (1995). Al-Mawrid a modern Arabic-English dictionary (7 ${ }^{\text {th }}$ ed.). Beirut, Lubnan: Dar El-IIm Lilmalayin.

Beckmann, H. B. (2013). Music, adolescents and health: Narratives about how young people use music as a health resource in daily life. Musical Life Stories, Narratives on Health Musicking, Centre for Music and Health Publication Series, 6 (5), 95 - 116.

Botek, A. M. (2020). Healing harmonies: Music therapy for seniors and caregivers. AgingCare. https://www.agingcare.com/articles/music-as-medicine-for-seniors-156581.htm. Retrieved on $21^{\text {st }}$ August 2020.

Brown, S., \& Jordania, J. (2011). Universals in the world's musics. Psychology of Music, 41 (2), 229 248.

Che Seman, Z., Awang Kechik, A. Z., \& Ahmad, Z. A. S. (2014). Nyanyian dan muzik mengikut pandangan hukum oleh Tuan Guru Hj. Abdul Rahman Pondok Sungai Durian Kuala Krai Kelantan. International Research Management and Innovative Conference 2014 (IRMIC2014), 17 - 18 November, Kuala Lumpur, 527 - 542. http://rmc.kuis.edu.my/irmic/wpcontent/uploads/2014/12/062-NYANYIAN-DAN-MUZIK-MENGIKUT-PANDANGAN-HUKUMOLEH-TUAN-GURU-HJ-ABDUL-RAHMAN.pdf. Retrieved on 20 ${ }^{\text {th }}$ August 2020.

Clark, I. N., \& Tamplin, J. (2016). How music can influence the body: Perspectives from current research. Voices: A World Forum for Music Therapy, 16 (2), 1 - 15.

Dearn, L. K. (2013). Young people and popular music culture the impact of popular music within the everyday lives of children aged 10 - 16. (Masters by Research, University of York, UK). http://etheses.whiterose.ac.uk/5705/1/LDMResBlackandWhite.pdf. Retrieved on $20^{\text {th }}$ August 2020.

Dukes, K. (2017). The Quranic Arabic corpus. UK: Language Research Group, University of Leeds. http://corpus.quran.com/qurandictionary.jsp?q=sEd. Retrieved on $18^{\text {th }}$ August 2020.

Dukes, K. (2017). The Quranic Arabic corpus. UK: Language Research Group, University of Leeds. http://corpus.quran.com/qurandictionary.jsp?q=rwH. Retrieved on $19^{\text {th }}$ August 2020.

Frishkopf, M. (2008). Music. In Rippin, A. (Ed.), The Islamic world (pp. 510 - 526). UK: Routledge Taylor \& Francis Group. 
INTERNATIONAL JOURNAL OF ACADEMIC RESEARCH IN BUSINESS AND SOCIAL SCIENCES Vol. 10, No. 10, 2020, E-ISSN: 2222-6990 @ 2020 HRMARS

Gottlieb, J. (2019). New Harvard study establishes music is universal. The Harvard Gazette. https://news.harvard.edu/gazette/story/2019/11/new-harvard-study-establishes-music-isuniversal/. Retrieved on $18^{\text {th }}$ August 2020.

Hanser, S. B., \& Thompson, L. W. (1994). Effects of a music therapy strategy on depressed older adults. Journal of Gerontology: PSYCHOLOGICAL SCIENCES, 49 (6), 265 - 269.

Howell, D. C. (2008). Fundamental statistics for the behavioral sciences ( $6^{\text {th }}$ ed.). CA, USA: Thomson Wadsworth.

Johnson, J. (2002). Who needs classical music?: Cultural choice and musical value. Oxford and New York: Oxford University Press.

Kent, D. (2006). The effect of music on the human body and mind. (Senior Thesis, Liberty University, US). https://digitalcommons.liberty.edu/cgi/viewcontent.cgi?article=1162\&context=honors. Retrieved on 10 September 2020.

Lai, H. L., \& Good, M. (2005). Music improves sleep quality in older adults. Journal of Advanced Nursing, 49 (3), $234-244$.

Letts, R. (1997). Music: Universal language between all nations? International Journal of Music Education, 29 (1), $22-31$.

Mehr, S. A., Singh, M., Knox, D., Ketter, D. M., Pickens-Jones, D., Atwood, S., Lucas, C., Jacoby, N., Egner, A. A., Hopkins, E. J., Howard, R. M., Hartshorne, J. K., Jennings, M. V., Simson, J., Bainbridge, C. M., Pinker, S., O'Donnell, T. J., Krasnow, M. M., \& Glowacki, L. (2019). Universality and diversity in human song. Science, 366 (6468), $1-17$.

Papinczack, Z. E., Dingle, G., Stoyanov, S., Hides, L., \& Zelenko, O. (2015). Young people's uses of music for well-being. Journal of Youth Studies, 18 (9), $1119-1134$.

Parman, M., Shahri, M. H., \& Marni, N. (2017). Al-Sama'menurut perspektif Ibn Arabi dalam nasyid kontemporari: Satu analisis konseptual. Social Sciences Postgraduate International Seminar (SSPIS) 2017, School of Social Sciences, USM, Pulau Pinang, Malaysia, 114 - 120. http://eprints.usm.my/39255/1/ART_16.pdf. Retrieved on 20 th August 2020.

Pusat Rujukan Persuratan Melayu. (2017). Kamus Dewan Edisi Keempat. Kuala Lumpur: Dewan Bahasa dan Pustaka. https://prpm.dbp.gov.my/Cari1?keyword=muzik. Retrieved on $17^{\text {th }}$ August 2020.

Pusat Rujukan Persuratan Melayu. (2017). Kamus Dewan Edisi Keempat. Kuala Lumpur: Dewan Bahasa dan Pustaka.

https://prpm.dbp.gov.my/Cari1?keyword=kebahagiaan\&d=176312\&\#LIHATSINI. Retrieved on $19^{\text {th }}$ August 2020.

Pusat Rujukan Persuratan Melayu. (2017). Kamus Dewan Edisi Keempat. Kuala Lumpur: Dewan Bahasa dan Pustaka.

https://prpm.dbp.gov.my/Cari1?keyword=Rohani\&d=176312\&\#LIHATSINI. Retrieved on $19^{\text {th }}$ August 2020.

Puvenesvary, M., Abdul Rahim, R., Naidu, S., R., Badzis, M., Nayan, M. N. F., \& Abd Aziz, N. H. (2008). Qualitative research: Data collection \& data analysis techniques. Sintok, Kedah Malaysia: Universiti Utara Malaysia Press.

Sa'ari, C. Z. (1997). Al-Ghazali's views on the heart, the spirit and the soul: A comparison between Ihya' 'Ulum Al-Din and Al-Risalah Al-Laduniyyah. Jurnal Usuluddin, 7, 193-208.

Samat@Darawi, A. B., Hamzah, A. R., Tibek, S. R., \& Muhamat@Kawangit, R. (2014). Seni berzanji dan marhaban: Sejarah dan amalannya dalam masyarakat Melayu (The art of berzanji and 
INTERNATIONAL JOURNAL OF ACADEMIC RESEARCH IN BUSINESS AND SOCIAL SCIENCES

Vol. 10, No. 10, 2020, E-ISSN: $2222-6990$ @ 2020 HRMARS

marhaban: History and practise in Malay society). 'Ulum Islamiyyah Journal, 14 (December), $43-55$.

Ulfa, M. (2017). Muslim pop: voicing da'wa through contemporary English nasyid love song lyrics in Southeast Asia. Advances in Social Sciences, Education and Humanities Research (ASSHER), $154,213-217$.

Wall, M., \& Duffy, A. (2010). The effects of music therapy for older people with dementia. British Journal of Nursing, 19 (2), $108-114$.

Yusof, A., \& Bidin, A. (2008). Perkembangan seni muzik dalam peradaban Islam di Nusantara. Journal of Al-Tamaddun, 3 (1), $48-67$. 